\title{
THE IMPORTANCE OF INSTITUTIONAL TRUST FOR FINANCIAL SERVICE PROVIDERS AMONG YOUNG ADULTS AND THEIR PARENTS IN AN EMERGING MARKET ${ }^{1}$
}

\author{
BOGLÁRKA ZSÓTÉR ${ }^{1}$ - ANDRÁS BAUER ${ }^{2}$ \\ ${ }^{1}$ Institute of Marketing and Media, Corvinus University of Budapest, Hungary \\ Email:boglarka.zsoter@uni-corvinus.hu \\ ${ }^{2}$ Institute of Marketing and Media, Corvinus University of Budapest, Hungary \\ Email: andras.bauer@uni-corvinus.hu
}

Trust in financial institutions can be seen as a foundation for loyalty and profits in the banking industry and is relevant for the macro economy as well. Young customers are more likely to lack trust due to their lack of personal experience in finance, although parental advice may lower their risk. In this paper the authors combine trust measures with intergenerational communication theory and test it on a large dyadic sample using Z-scores. The results show a strong, holistic intergenerational effect on institutional trust, but shed light on heterogeneity in the sample due to gender, financial independence and different communication styles.

Keywords: institutional trust, financial service providers, young adults, financial socialization, intergenerational effects

JEL-codes: D14, O16

This work was created in commission of the National University of Public Service under the priority project KÖFOP-2.1.2-VEKOP-15-2016-00001 titled "Public Service Development Establishing Good Governance" and Budapest Metropolitan University. 


\section{INTRODUCTION}

The global financial crisis and other negative events in banking markets have eroded trust in financial institutions. Trust in personnel and in managerial policies (Sirhdesmukh et al. 2002) increases loyalty (mediated by perceived value), and loyalty may lead to higher markets share and lower costs of operation (Worcester 1997). Perceived trust may depend on personal experiences and even though most young customers may lack these experiences, they still have to make financial decisions, such as selecting services providers and financial products. To decide, they may learn from advertising messages or use natural sources of learning, such as parental advice.

This study is placed in an emerging European country, Hungary, where financial literacy is relatively low compared to established markets (OECD 2014), so it is an open question whether parents providing advice to their offspring are well situated to be reliable sources.

The role of intergenerational influences is widely studied, but relatively few studies deal with actual market choices, or if so, mainly do so in the fast moving consumer goods markets (Moore et al. 2002), and not in financial ones. This study aims to close this gap in the literature by developing a unique dataset of parents and children to measure similarities and differences.

\section{LITERATURE REVIEW}

\subsection{Institutional trust}

Institutional trust as an element of social cohesion has been widely researched in different fields of socials sciences. According to Möllering (2005), trust can take different forms including being based on rational expectations, or on a beliefbased social routine (called institutional trust by Möllering), and/or on experimentation. While trust has to have a rational foundation, it requires faith as well. Experimentation and communication can help to maintain trust even in a rapidly changing environment, albeit this requires decisions carried out in good faith by institutional actors.

We argue that in the Hungarian finance macro-scene (e.g. in providing foreign currency based loans), these principles might have been hurt for a certain time period. This could be one reason while institutional trust levels in Hungary (and in Central-Eastern Europe) have been significantly lower than in Western Europe. According to Boda and Medve-Bálint (2014) these differences are not rooted in the different value systems (e.g. materialism) or economic/demographic variables 
of citizens in different economies, but are related to the performance of specific institutions, e.g. of banks.

On the corporate level, the existence or lack of trust is key for efficient business practices. The presence of trust can lower transactions costs and vice versa (Williamson 1993). In our investigation, we focus on a specific age group which may not have significant personal experience in financial matters, young customers. Based on longitudinal research results, Ennew et al. (2010) argued that trust ratings are highest among older customers. Money-related knowledge, attitudes and behaviour, as well as materialistic orientation are becoming ingrained during the process of consumer socialization (Ilmonen 2011; McNeal 1992). Learning to deal with money is related to early economic experiences (Shim et al. 2010); indeed, Roedder John (1999) defines consumer and financial behaviour as a learning process during which children acquire knowledge, skills and competences to collect and spend money rationally, and to behave economically reasonably (Nagy - Tóth 2012). Shim et al. (2013) investigated the financial behaviour and opinions of US university students and found that the level of trust was declining: in 2009 it was lower than a year earlier. A further finding relates to self-reported well-being and financial status (determined by parents' socioeconomic status and total debt level), which significantly influence young adult consumers' level of trust in banks and financial institutions.

The financial behaviour of young adults is an important research topic for various fields. In parallel with the development of financial markets, financial products have also become more complex and often more complicated. Personal financial needs have changed over time (Habschick et al. 2007; Botos et al. 2012). Unfortunately, the complex nature of needs and markets goes with the low level of financial knowledge and financial culture (Chen - Volpe 1998; Volpe et al. 2006; Lusardi - Mitchell 2014). There has been both scientific and practical interest in this field in Hungary. In the past years some interesting research has been published in the field of financial attitudes, behaviour and literacy (Béres - Huzdik 2012; Kovács et al. 2011; Hornyák 2015; Zsótér et al. 2015), offering insights that can be used in the investigation of institutional trust among young adults.

\subsection{Parental influence}

Family is regarded as the primary socialization agent in children's lives. This statement is true for consumer behaviour in general (e.g. Caruana - Vassallo 2003; Moschis et al.1986), and for consumer finances as well (e.g. Webley Nyhus 2012; Rettig 1983). Family structure has an impact on the child's decision making, including sex-based parental roles. For example, Kim et al. (2009) 
have studied same-sex influences and developed a measurement for children's consumption decisions. Family can be seen as primary socialization agent in the process of financial socialization as well, where children living in a family can listen to their parents, are involved in family finances and receive direct instructions on how to manage money (Beutler - Dickson 2008; Pinto et al. 2005; Danes 1994). Parents play multiple roles in the process of financial socialization including the following elements: providing pocket money, establishing expectations, indulgence, presenting a role model, and communication about finances.

Parents may have a strong influence on children's decision-making, but the children's personal experiences may play an important role as well. While in some choices one can observe a pass-down behavioural pattern, when children follow their parents' choices, in other cases they express their independence in changing the brand or the buying practice (e.g. Moore et al. 2001). While Kim et al. (2009) focused on general decision-making, Luksander et al. (2014) found that higher personal financial experience among Hungarian high-school students increased their financial literacy rating, which provides them with better foundations when making decisions. Family life dynamics, parental goals and children's personal experience are all reflected in the communication patterns (Koerner Fitzpatrick 2002) across generations.

\subsection{Intergenerational communication theories}

Research into intergenerational influence in the field of consumer behaviour and brand management attempts to explore how consumer behaviour patterns, values, orientations and attitudes are handed down from one generation to the other (Moore et al. 2002). Research often uses intergenerational influence as a synonym for family influence (Childers - Rao 1992; Moschis 1985). The field of the intergenerational influence and the socialization within the family connect at a certain point, namely through family communication. That is why one of the most important elements of our research is the theory of family communication patterns (McLeod - Chaffee 1972; Ritchie - Fitzpatrick 1990). Communication is the central element of family functions, thus it is an unavoidable research area in socialization and intergenerational influence (Schrodt 2005).

Family communication patterns frequently emerge in consumer behaviour studies. The family communication patterns scale has been adapted to consumer behaviour (Moschis - Moore 1979), and has been used widely in consumer behaviour research (e.g. by Kim et al. 2009; Clarke 2008). McLeod et al. (1967) identified that families or couples may come to agreement in two different ways. The first option is when family members discuss an issue with each other, and then accept this evaluation. Practically, they conform to other members, and the 
Table 1. Family communication patterns

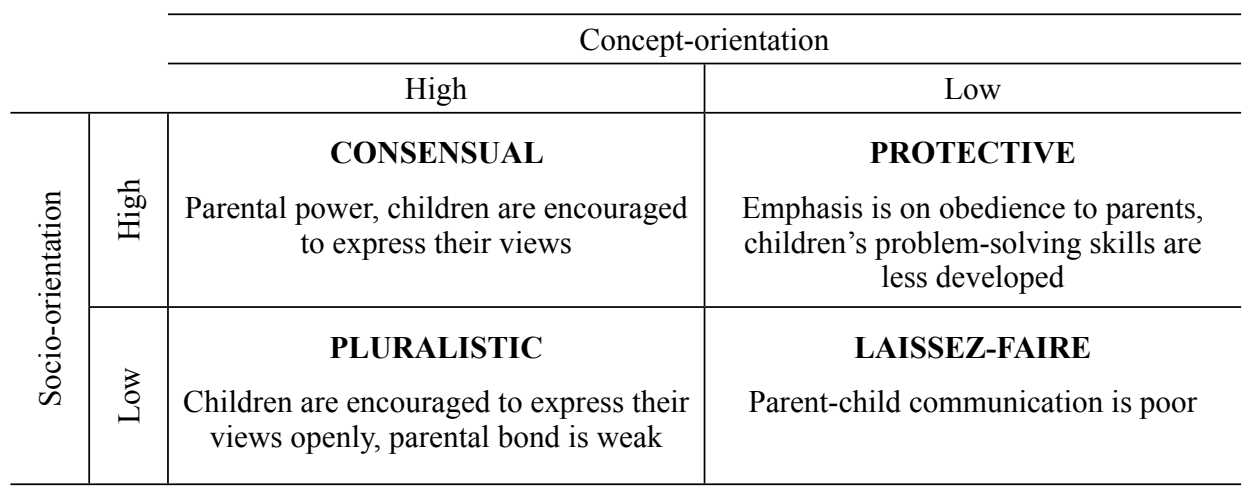

Source: Neulinger (2011) based on Ritchie and Fitzpatrick (1990)

emphasis in this process is on the relationship between family members, called socio-orientation. The other mode - concept-orientation - is when family members create a common perception of things in their environment. In this case, the emphasis is on the manner family members define the thing in question. Thus, the basis of the communication style is the creation of a common social reality within the family (Graham 2011). The outcome can be represented as a dichotomy between the two orientations (socio- and concept-orientation), taking low or high values, thus defining four family communication styles (see Table 1).

Consensual families are high both in concept-orientation and socio-orientation, thus there is, concurrently, a pressure to obey parents and encourage children to express their views openly, hence family members tend to share the same opinion on basic things, and usually agreement prevails in the family. In consensual families children more often experience rejection of their whish when parents find them unsubstantiated, which supports experiential leaning. A protective communication climate prevails in families that are high in socio-orientation and low in concept-orientation, therefore emphasis is on obedience to parents and on social harmony. Children in these families have less developed problem-solving skills, as parents do not regard it important to encourage children to process information and to form opinion independently. In pluralistic families the levels of dimensions are the opposite, namely, families are high in concept-orientation and low in socio-orientation. Children's opinion is usually accepted, and children are encouraged to develop skills and abilities, such as problem-solving skills, resulting in more developed skills. Laissez-faire families are low in both communication orientations, communication is poor between parents and children, parents fail to lay stress both on control and self-reliance (Caruana - Vassallo 2003; Graham 2011; Neulinger 2011; Neulinger - Zsótér 2012). 
However, intergenerational influence is a multi-factor affected phenomenon (Moore et al. 2001; Moore et al. 2002; Lyons et al. 2006). The same way as gender roles or family communication patterns affect the degree of transmission within the family regarding attitudes, values and norms (Odenweller 2011), one can assume there could be other factors with similar effects. One additional factor that can be considered in connection with young adults' financial socialization is their financial independence. Reflecting back to Möllering's (2005) conceptualization of trust, financially independent young adults may exercise active trust.

\section{THE RESEARCH PROBLEM}

The paper's central theme relates to the intergenerational influence on young adults' trust in financial institutions. Specifically, we aimed to test the following questions:

1. Is there a parental influence on the trust in financial institutions of young adults? This question is based on family studies (e.g. Moschis et al. 1986, or specifically in the financial domain Beutler and Dickson 2008).

2. What moderates parental influence on the financial institutional trust of young adults? In this domain - based on our previous literature analysis we aimed to test the influence of family structure (is there a same-sex influence) and the communication style in the family.

2a. Does same-sex influence exist in young adults' trust in financial institutions? In this, we are reflecting on the findings of Kim et al. (2009), modified to financial institutions using the scale of Béres et al. (2013) for the dependent variable

2b. Would the influence of parents on young adults' trust in financial institutions differ in terms of the communication styles within families? In this we refer to Kim et al. (2009), who claim differences across family communication patterns.

3. Will higher financial independence of young adults have an impact on how parents influence young adults' trust in financial institutions? Here we refer to the previous findings of e.g. Luksander et al. (2014).

\section{METHODOLOGY AND SAMPLING PROCEDURES}

Most studies in intergenerational influences within the family put only one family member into focus, and explore the existence or absence of parental influence from a single point of view (Odenweller 2011; Kim et al. 2009). To provide a 
more differentiated view, we decided to measure the same variables from the perspective of both parties. We wanted to explore young adults' financial socialization but not only from their own point of view, but to consider their parent's answers as well, thereby offering a complex interpretation of the problem using a paired sample, where intergenerational influence is assessed on both respondent groups via a questionnaire. Both students and their parents were asked to fill in an online questionnaire. In order to be able to identify the student-parent dyads at the end of the data collection period, students' university identification codes were used and were deleted after successful pairing. The latter method allowed us to perform both a random and actual pairing of the two samples (student and parent). At the end of the data collection period, a database of 602 student-parent dyads was obtained. After data cleaning, the database was ultimately composed of 535 student-parent dyads. For the sake of comparison, the study that constituted the starting point for the present work (Moore et al. 2002) included 102 daughter-mother dyads to analyse intergenerational effects within the family. Table 2 shows baseline statistics for the student and parent samples.

Our sample is skewed in certain aspects; average income is higher; and families involved in the sample have reported less financial trouble than the Hungarian national average. While this certainly represents a limitation for generalizing our findings, we believe that financial knowledge and the financial independence of participants could be higher than in their cohorts. Further, the distribution of communication patterns within the sample is similar to the national average (Neulinger 2011), with some skew towards the laisse-faire communication style. Based on the institutional trust scale (Béres et al. 2013), we calculated scores for both subsamples and categorized them (low, medium, high), and checked how

Table 2. Baseline statistics of the student and parent samples

\begin{tabular}{l|c|c}
\hline & $\begin{array}{c}\text { Student sample } \\
(\mathrm{N}=535)\end{array}$ & $\begin{array}{c}\text { Parent sample } \\
(\mathrm{N}=535)\end{array}$ \\
\hline Gender & $37.6 \%$ & $27.3 \%$ \\
\hline Male & $62.4 \%$ & $72.3 \%$ \\
\hline Female & $32.0 \%$ & $29.2 \%$ \\
\hline Main residence & $49.5 \%$ & $54.6 \%$ \\
\hline Budapest (capital city) & $8.2 \%$ & $8.0 \%$ \\
\hline Other town & $8.2 \%$ & $8.2 \%$ \\
\hline Minor municipality & $\begin{array}{c}54,517 \mathrm{HUF} \\
(175 \mathrm{EUR})\end{array}$ & $\begin{array}{c}313,524 \mathrm{HUF} \\
(1,000 \mathrm{EUR})\end{array}$ \\
\hline Monthly average income &
\end{tabular}

Source: authors 
many participants we found in the three categories for both parents and children. After this, we used Kanji's (1993) Z-test to assess significance of findings.

We studied the theory of family communication patterns in two research domains. Communication science is one of the areas that is based on this study, and the Revised Family Communication Patterns Scale designed by Ritchie and Fitzpatrick (1990) has become widely used. In the area of consumer behaviour, the scale of Moore and Moschis (1981) is applied. More recent consumer socialization studies also apply this scale, such as Kim et al. (2009), or Caruana and Vassallo (2003). The scale of Ritchie and Fitzpatrick (1990) is longer and was designed to explore family communication styles in general, whereas Moore and Moschis (1981) scale is specified to consumption-related research, thus it seems to be more suitable to investigate consumer financial behaviour. The two dimensions of the scale (concept-orientation and socio-orientation) and their items ranging from 1 (strongly disagree) to 5 (strongly agree) are as follows (see Table 3):

One statement of concept-orientation failed to fit into the original factor structure (She/he lets me decide which things I should or shouldn't buy). Furthermore, two more statements had to be excluded from the concept-orientation because of the low factor loading. The scale has become more balanced as statements in the two orientations are similar in number. In the final factor structure on the student sample, KMO was 0.752 . Factor analysis was performed on the student sample, and the value of Cronbach's alpha on concept-orientation was 0.72 , and on socioorientation 0.745 .

Table 3. Items of Family Communication Pattern Scale by dimension - adjusted to students

\begin{tabular}{l}
\hline Concept-orientation \\
\hline My mother (father) asks me to help her buy things for the family. \\
\hline She (he) asks me my preference when she buys something for me. \\
\hline She (he) talks to me about where different products can be bought. \\
\hline She (he) lets me decide which things I should or shouldn't buy. \\
\hline She (he) asks me for advice about buying things. \\
\hline My mother (father) and I talk about buying things. \\
\hline She (he) asks me about things that she buys for herself. \\
\hline She (he) asks me what I think about things I buy for myself. \\
\hline Socio-orientation \\
\hline My mother (father) tells me what things I should or shouldn't buy. \\
\hline She (he) tells me that I'm not allowed to buy certain things. \\
\hline She (he) wants to know what I do with my money. \\
\hline She (he) complains when she (he) doesn't like something that I bought for myself. \\
\hline She (he) tells me not to buy certain things. \\
Source: Kim et al. (2009)
\end{tabular}




\section{RESULTS}

First we report findings about institutional trust, which is relatively low both for parents and students, measured on a 5 point Likert-scale. Overall, students seem to trust institutions more than their parents, as is shown in Table 4. Clearly however, banks and insurance companies are not trusted too much regarding fulfilling the contractual requirements, which could be in line with the findings of Boda and Medve-Bálint (2014).

Table 4. Mean values of institutional trust for parents and students $(\mathrm{N}=535)$

\begin{tabular}{|c|c|c|c|}
\hline & & \multicolumn{2}{|c|}{ Means } \\
\hline $\begin{array}{l}\text { Institutional trust scale items } \\
\text { (based on Béres et al. 2013) }\end{array}$ & $\mathbf{N}$ & Students & Parents \\
\hline $\begin{array}{l}\text { Banks and insurance companies always fulfil } \\
\text { the contracts }\end{array}$ & 535 & 3.08 & 2.86 \\
\hline Loans contribute to the welfare of the society & 535 & 3.32 & 3.12 \\
\hline Bank employees are helpful and competent & 535 & 3.64 & 3.53 \\
\hline Your money is safe in the banks & 535 & 3.67 & 3.46 \\
\hline Using bank cards is safe & 535 & 3.78 & 3.59 \\
\hline
\end{tabular}

Source: authors

After this, we calculated the $\mathrm{Z}$ scores based on the match of both random (no family influence is present) and actual pairs, for both parents and students. If the difference of expected number of dyads categorized into the same category is significant in the two samples (random and actual) we can conclude that the intergenerational effect exists. During calculation the following formulas were applied (Kanji 1993; Moore et al. 2002):

$$
\begin{aligned}
& \mathrm{E}=\mathrm{n} \times\left[\left(\mathrm{p}_{\mathrm{h} 1} \times \mathrm{p}_{\mathrm{sz} 1}\right)+\left(\mathrm{p}_{\mathrm{h} 2} \times \mathrm{p}_{\mathrm{sz} 2}\right)+\left(\mathrm{p}_{\mathrm{h} 3} \times \mathrm{p}_{\mathrm{sz} 3}\right)\right] \\
& \mathrm{A}=2 \times\left(\mathrm{M}_{1}+\mathrm{M}_{2}+\mathrm{M}_{3}\right) \\
& \mathrm{Z}=(\mathrm{A} / \mathrm{n}-\mathrm{E} / \mathrm{n}) /\{[\mathrm{E} / \mathrm{n} \times(1-\mathrm{E} / \mathrm{n})] / \mathrm{n}\}^{1 / 2}
\end{aligned}
$$

where

- $\mathrm{p}_{\mathrm{h} 1-3}=$ the proportion of students (children) falling into the given category of the given variable

- $\mathrm{p}_{\mathrm{sz1}-3}=$ the proportion of parents falling into the given category of the given variable

- $\mathrm{M}_{1-3}=$ number of dyads effectively categorized into the given category

- $\mathrm{n}=$ sample size 
- $\mathrm{E}=$ the total number of subjects in the random pairing sample who fall into the same category as their pairs

- $\mathrm{A}=$ the total number of subjects in the actual pairing sample who fall into the same category as their pairs

We calculated the $\mathrm{Z}$ score for institutional trust $(\mathrm{Z}=10.349)$ which was significant on the 0.001 level. It met our expectations that the family has a significant effect on institutional trust in our sample. Furthermore, based on regression analysis, we found that parental trust in institutions has the same valence in case of their children as well, and this effect is significant (Table 5).

Table 5. Results of the regression analysis of parents' institutional trust on the institutional trust of their children

\begin{tabular}{l|l|c|c|c|c|c}
\hline \multicolumn{2}{c|}{ Hypothetical effect } & B & $\boldsymbol{\beta}$ & $\mathbf{t}$ & $\mathbf{R}^{2}$ & F \\
\hline Inst_trust_parent & Inst_trust_student & 0.385 & 0428 & $10.934^{* *}$ & 0.183 & $119.550^{* *}$ \\
\hline
\end{tabular}

Note: ** denotes significance at the $1 \%$ level

Source: authors

In a further analysis we looked at the impact on intergenerational communication styles on institutional trust and formulated two hypothesis:

- Hypothesis 1: Families characterized by high concept- and high socio-orientation (i.e. where parents exercise a resolute control and consciously encourage autonomy at the same time [consensual communication style]) are expected to have a higher impact on their young adult children's financial socialization than in the remaining subsamples.

- Hypothesis 2: In families where parents do not seek to control their young adult children, nor to encourage their autonomy, the results are expected to be the lowest compared to the remaining subsamples.

We split the sample into four subsamples representing different communication styles: consensual, pluralistic, protective and laissez-faire. The regression analysis in Table 6 shows a variably strong, but significant effect of parental influence that is strongest in families with consensual, and weakest in families with pluralistic communications styles. Since the effect is relatively weak in the laissez-faire communication subsample, only our first hypothesis was proven correct.

Since marketers and regulators may want to communicate more efficiently to young adults and/or their parents, we included within-family gender roles into our analysis, splitting the sample into four subsamples. The findings in Table 7 show that younger males are better influenced by their parents than younger fe- 
Table 6. Values of the determination coefficients obtained from the regression analysis of the four communication subsamples

\begin{tabular}{|c|c|c|c|c|c|c|}
\hline \multicolumn{2}{|c|}{ Hypothetical effect } & $\mathbf{R}^{2}(\mathbf{c})$ & $\mathbf{R}^{2}(\mathbf{p l})$ & $\mathbf{R}^{2}$ (pr) & $R^{2}$ (lf) & $\mathbf{R}^{2}$ \\
\hline Inst_trust parents & Inst_trust_students & $0.259^{* *}$ & $0.119 * *$ & $0.160 * *$ & $0.153 * *$ & $0.183 * *$ \\
\hline
\end{tabular}

Notes: $* *$ denotes significance at the $1 \%$ level. C: consensual, pl: pluralistic, pr: protective, lf: laissez-faire Source: authors

Table 7. Values of the determination coefficients obtained from the regression analysis of the four parental role subsamples

\begin{tabular}{c|l|c|c|c|c|c}
\hline \multicolumn{2}{|c|}{ Hypothetical effect } & $\begin{array}{c}\mathbf{R}^{2} \\
\text { (mother- } \\
\text { daughter) } \\
\mathbf{N = 2 6 0}\end{array}$ & $\begin{array}{c}\mathbf{R}^{2} \\
\text { (mother- } \\
\text { son) } \\
\mathbf{N = 1 2 9}\end{array}$ & $\begin{array}{c}\mathbf{R}^{2} \\
\text { (father- } \\
\text { daughter) } \\
\text { N=74 }\end{array}$ & $\begin{array}{c}\mathbf{R}^{2} \\
\text { (father- } \\
\text { Son) } \\
\mathbf{N = 7 2}\end{array}$ & $\begin{array}{c}\mathbf{R}^{2} \\
\text { (entire } \\
\text { sample) }\end{array}$ \\
\hline Inst_trust parents & Inst_trust_students & $0.164^{* *}$ & $0.200^{* *}$ & $0.086^{*}$ & $0.335^{* *}$ & $0.183^{* *}$ \\
\hline
\end{tabular}

Notes: ** denotes significance at the $1 \%$ level

Source: authors.

males and this may have an impact on passing opinions about institutional trust. Interestingly, this effect is strongest between fathers and sons.

One additional factor that can be considered in connection with young adults' financial socialization is their financial independence. In the questionnaire students were asked to what extent they felt to be financially independent, and when they hoped to be fully independent. Cluster analysis performed on the questions yielded the following three groups:

- Cluster 1: not independent at all, and they intend to separate from the parents at a later time $(\mathrm{N}=123)$;

- Cluster 2: fully independent ( $\mathrm{N}=117)$;

- Cluster 3: almost fully independent but they need some time to be fully independent financially $(\mathrm{N}=295)$.

The not independent group has a high proportion of males, and most of them live in full families. Students relying on their parents as a source of income represent the largest here $(91.1 \%)$, and the use of student loans are the lowest $(8.9 \%)$. The partially independent cluster accounts for the highest proportion $(64.1 \%)$ of women. The proportion of those who have a monthly plan is high in this group. The fully independent group accounts for the largest proportion of students who permanently live in a town. It has high percentage of one-parent families and shows the lowest dependence on parents. Cluster members tend to have their own income and have higher levels of job experience. Not surprisingly, there is a high 
Table 8. Values of the determination coefficients obtained from the regression analysis of the financial independence clusters

\begin{tabular}{l|l|c|c|c|c}
\hline \multicolumn{2}{c|}{ Hypotethical effect } & $\begin{array}{c}\mathbf{R}^{2} \\
\text { (not indep.) } \\
\mathbf{N}=\mathbf{1 2 3}\end{array}$ & $\begin{array}{c}\mathbf{R 2} \\
\text { (partly } \\
\text { indep.) } \\
\mathbf{N = 2 9 5}\end{array}$ & $\begin{array}{c}\mathbf{R}^{2} \\
\text { (fully } \\
\text { indep.) } \\
\mathbf{N}=117\end{array}$ & $\begin{array}{c}\mathbf{R}^{2} \\
\text { (entire } \\
\text { sample) }\end{array}$ \\
\hline Inst_trust_parents & Inst_trust_students & $0.258^{* *}$ & $0.173^{* *}$ & $0.140^{* *}$ & $0.183^{* *}$ \\
\hline
\end{tabular}

Notes: ** denotes significance at the $1 \%$ level

Source: authors.

level of student loans in this cluster. Interestingly (Table 8), the more financially independent respondents considered themselves, the less they trusted financial institutions, which could represent a critique of existing financial services and is in line with previous findings (OECD 2014).

\section{CONCLUSIONS}

Our research sheds light into how intergenerational influences are created in financial matters, especially in terms of institutional trust. We looked beyond the existence of the basic effect that was reported previously in the extant literature and used variables, such as gender roles, communication styles and whether young adults handle their personal finances independently. We found significant effects for all variables that can enhance our knowledge about the interaction of trust, communication styles and gender roles. Furthermore, we found significant interactions between financial independence and gender that opens future research opportunities and may be important for financial education as well.

Beyond academic sources, our findings match research results of financial services providers and research companies regarding financial trust in Hungary. Previously, Groupama Insurance found low institutional trust in the insurance market, and GfK found it alarming that parents cannot effectively communicate with their children and pass over information.

This research has managerial implications not only for banks and insurance companies, but for regulators as well. First, the implications are clear that acquiring young adults as first-time clients needs to be done in multiple ways, through education, advertising and influencing parents. Parents may play an important role in this process due to the existence of intergenerational communication effects within families. Second, service providers may want to better target their messages to a heterogeneous audience where the source of heterogeneity may come from gender, family wealth or independence. These variables can be measured and used in communication more effectively. Third, financial service pro- 
viders may want to discover ways to research the existence of different withinfamily communication styles in their target audiences, since families represented by these styles differ in their trust levels.

Regulators and educators can use our findings as well. It is paramount for the whole society to increase trust in the financial system and these institutions can play their role in designing better public communication campaigns targeting not only young adults, but their parents as well.

\section{REFERENCES}

Beutler, I. - Dickson, L. (2008): Consumer Economic Socialization. In: Xiao, J. J. (ed.): Handbook of Consumer Finance Research. New York: Springer, pp. 83-103.

Béres, D. - Huzdik, K. (2012): A pénzügyi kultúra megjelenése makrogazdasági szinten [The Macroeconomic Presence of Financial Culture]. Public Finance Quarterly 2012(3): 322-336.

Béres, D. - Huzdik, K. - Kovács, P. - Sápi, Á. - Németh, E. (2013): Felmérés a felsőoktatásban tanuló fiatalok pénzügyi kultúrájáról [Research on Financial Literacy of Hungarian University and College Students]. http://www.asz.hu/tanulmanyok/2013/kutatasi-jelentes-felmeres-afelsooktatasban-tanulo-fiatalok-penzugyi-kulturajarol/t353.pdf, accessed 10/09/2014

Boda, Z. - Medve-Bálint, G. (2014): Does Institutional Trust in East Central Europe Differ from Western Europe? European Quarterly of Political Attitudes and Mentalities 3(2): 1-17.

Botos, K. - Botos, J. - Béres, D. - Csernák, J. - Németh, E. (2012): Pénzügyi kultúra és kockázatvállalás a közép-alföldi háztartásokban [Financial Literacy and Risk-Taking of Households in the Hungarian Central Great Plain]. Public Finance Quarterly 2012(3): 291-309.

Chen, H. - Volpe, R. P. (1998): An Analysis of Personal Financial Literacy among College Students. Financial Services Review 7: 107-128.

Caruana, A. - Vassallo, R. (2003): Children's Perception of Their Influence over Purchases: The Role of Parental Communication Patterns. Journal of Consumer Marketing 20(1): 55-66.

Childers, T. - Rao, A. (1992): The Influence of Familial and Peer-Based Reference Groups on Consumer Decisions. Journal of Consumer Research 19: 198-211.

Clarke, P. (2008): Parental Communication Patterns and Children's Christmas Requests. Journal of Consumer Marketing 25(6): 350-360.

Danes, S. (1994): Parental Perception of Children's Financial Socialization. Financial Counselling and Planning 5: 127-149.

Ennew, C. - Kharouf, H. - Sekhon, H. (2010): Trust in UK Financial Services: A Longitudinal Analysis. Journal of Financial Services Marketing 16(1): 65-75.

Graham, E. E. (2011): Revised Family Communication Patterns Instrument (RFCP). In: Rubin, R. B. - Rubin, A. M. - Graham, E. - Perse, E. M. - Seibold, B. (eds.): Communication Research Measures II. A Sourcebook. New York: Routledge, pp. 314-317.

Habschick, M. - Seidl, B. - Evers, J. (2007): Survey of Financial Literacy Schemes in the EU27. http://ec.europa.eu/internal_market/finservices-retail/docs/capability/report_survey_en.pdf, accessed 03/01/2012.

Hornyák, A. (2015): Attitüdök és kompetenciák a középiskolás diákok, mint potenciális banki ügyfelek körében [Attitudes and Competencies of High School Students as Potential Customers of Banks]. Doctoral dissertation, University of West Hungary. 
Ilmonen, K. (2011): A Social and Economic Theory of Consumption. London: Palgrave MacMillian.

Kanji, G. K. (1993): 100 Statistical Tests. Newbury Park, CA: Sage.

Kim, C. - Lee, H. - Tomiuk, M. A. (2009): Adolescents' Perceptions of Family Communication Patterns and Some Aspects of Their Consumer Socialization. Psychology and Marketing 26(10): 888-907.

Koerner, A. F. - Fitzpatrick, M. A. (2002): Toward a Theory of Family Communication. Communication Theory 12: 70-91.

Kovács, P. - Kosztopulosz, A. - Révész, B. - Kiss, G. D. - Székelyhidi, K. - Tulkán, T. - ÁrvaTóth, A. (2011): Középiskolások pénzügyi kultúrájának felmérése - Összefoglaló tanulmány. [Research on Financial Literacy of Highschool Students - Summary of Results] http://econventio. hu/\#letoltheto-dokumentumok/penzugyi-kultura-felmeres-2011-tanulmany, accessed 27/07/2012.

Lyons, A. C. - Scherpf, E. - Roberts, H. (2006): Financial Education and Communication between Parents and Children. The Journal of Consumer Education 23: 54-76.

Luksander, A. - Béres, D. - Huzdik, K. - Németh, E. (2014): Analysis of the Factors that Influence the Financial Literacy of Young People Studying in Higher Education. Public Finance Quarterly 59(2): 220-241.

Lusardi, A. - Mitchell, O. S. (2014): The Economic Importance of Financial Literacy: Theory and Evidence. Journal of Economic Literature 52(1): 5-44.

McLeod, J. M. - Chaffee, S. H. (1972): The Construction of Social Reality. In: Tiedeschi, J. T. (ed.): The Social Influence Process. Chicago: Aldine Atherton, pp. 50-99.

McLeod, J. M. - Chaffee, S. H. - Wackman, D. B. (1967): Family Communication: An Updated Report. Boulder: Association for Education in Journalism.

McNeal, J. U. (1992): Kids as Customers. Lexington: Lexington Books.

Moore, E. S. - Wilkie, W. L. - Adler, J. A. (2001): Lighting the Torch: How do Intergenerational Influences Develop? In: Gilly, M. C. - Meyers-Levy, J. (eds): Advances in Consumer Research. Valdosta: Association for Consumer Research, pp. 287-293.

Moore, E. S. - Wilkie, W. L. - Lutz, R. J. (2002): Passing the Torch: Intergenerational Influences as a Source of Brand Equity. Journal of Marketing 66(2): 17-37.

Moore, R. L. - Moschis, G. P. (1981): The Role of Family Communication in Consumer Learning. Journal of Communication 31(4): 42-51.

Moschis, G. P. (1985): The Role of Family Communication in Consumer Socialization of Children and Adolescents. Journal of Consumer Research 11(4): 898-913.

Moschis, G. P. - Moore, R. L. (1979): Family Communication and Consumer Socialization. Advances in Consumer Research 6: 359-363.

Moschis, G. P. - Prahasto, A. E. - Mitchell, L .G. (1986): Family Communication Influences on the Development of Consumer Behaviour: Some Additional Findings. Advances in Consumer Research 13(1): 365-369.

Möllering, G. (2005): Rational, Institutional and Active Trust: Just do It. In: Bijlsma-Frankema R. K. - Woolthuis, K. (eds): Trust under Pressure: Empirical Investigations of Trust and Trust Building in Uncertain Circumstances. Cheltenham: Elgar Publishing, pp. 17-36.

Nagy, P. - Tóth, Zs. (2012): Értelem és érzelem. A lakossági ügyfelek gazdasági magatartása és a bankokkal kapcsolatos attitüdjei [Sense and Sensibility. Retail Customer Behaviours and Attitudes towards Bank]. Financial and Economic Review 2012(10): 13-24.

Neulinger, Á. (2011): Családon belüli kommunikáció és a referenciacsoport hatása egyszülös és teljes családokban [Family Communication and the Effect of Reference Group in Single-Parent and Nuclear Families]. Conference of Marketing Teachers, 29-30 August 2011, Pécs, Hungary. 
Neulinger, Á. - Zsótér, B. (2012): Mennyire önállóak a fiatal felnőttek vásárlásaikban? A családi környezet befolyásának vizsgálata fiatal felnött gyermekek vásárlására [How Independent are Young Adults in Their Buying Decisions? Investigation of Family Influence on Young Adults' Buying Behaviour]. Conference of Marketing Teachers, 30-31 August 2012, Miskolc, Hungary.

Odenweller, K. G. (2011): Father-Son Family Communication Patterns and Gender Ideologies: A Modeling and Compensation Analysis. Thesis. West Virginia University.

OECD (2014): OECD Economic Economic Surveys 2014: Hungary. Paris: OECD Publishing.

Pinto, M. B. - Parente, D. H. - Palmer, T. S. (2000): Materialism and Credit Card Use by College Students. Psychological Reports 86(2): 643-652.

Rettig, K. D. (1983): Family as Economic Socialization Agent. Illinois Teacher of Home Economics 27(1): 5-7.

Ritchie, L. D. - Fitzpatrick, M. A. (1990): Family Communication Patterns: Measuring Intrapersonal Perceptions of Interpersonal Relationships. Communication Research 17(4): 523-544.

Roedder John, D. (1999): Consumer Socialization of Children: A Retrospective Look at TwentyFive Years of Research. Journal of Consumer Research 26(3): 183-213.

Schrodt, P. (2005): Family Communication Schemata and the Circumplex Model of Family Functioning. Western Journal of Communication 69: 359-376.

Shim, S. - Barber, B. L. - Card, N. A. - Xiao, J. J. - Serido, J. (2010): Financial Socialization of First-Year College Students: The Roles of Parents, Work, and Education. Journal of Youth and Adolescence 39 (1):1457-1470

Shim, S. - Serido, J. - Tang, C. (2013): After the Global Financial Crash: Individual Factors Differentiating Young Adult Consumers' Trust in Banks and Financial Institutions. Journal of Retailing and Consumer Services 20(1): 26-33.

Sirdeshmukh, D. - Singh, B. - Sabol, B. (2002): Consumer Trust, Value, and Loyalty in Relationship Exchanges. Journal of Marketing 66(1): 15-37

Volpe, R. - Chen, H. - Liu, S. (2006): An Analysis of the Importance of Personal Finance Topics and the Level of Knowledge Possessed by Working Adults. Financial Services Review 15(1): 81-98.

Webley, P. - Nyhus, E. K. (2012): Economic Socialization, Saving and Assets in European Young Adults. Washington University in St. Louis CSD Working Papers No. 12-01.

Williamson, O. E. (1993): Calculativeness, Trust and Economic Organization. The Journal of Law \& Economics 36(1): 453-486.

Worcester, R. M. (1997): Managing the Image of Your Bank: The Glue that Binds. International Journal of Bank Marketing 15(5): 146-152.

Zsótér, B. - Béres, D. - Németh, E. (2015): A magyar fiatalok jellemzése pénzügyi attitűdjeik és magatartásuk mentén - Vizsgálat a felsőoktatásban tanulók pénzügyi attitűdjeiről és magatartásáról. [Characterisaiton of Young Adults Based on Their Financial Attitudes and Behaviour - Investigation of University Students' Financial Attitudes and Behaviour] Budapest Management Review 46(6): 70-80.

Open Access. This is an open-access article distributed under the terms of the Creative Commons Attribution 4.0 International License (https:/creativecommons.org/licenses/ by/4.0), which permits unrestricted use, distribution, and reproduction in any medium, provided the original author and source are credited, a link to the CC License is provided, and changes - if any - are indicated. (SID_1) 